\title{
Export of environmental technologies by publicly-owned companies: Approaches, drivers and obstacles among Swedish municipal companies
}

\author{
Wisdom Kanda, Olof Hjelm, Kajsa Kairento and Marcus Nygårds \\ Journal Article
}

\section{Tweet}

N.B.: When citing this work, cite the original article.

This is an electronic version of an article published in:

Wisdom Kanda, Olof Hjelm, Kajsa Kairento and Marcus Nygårds, Export of environmental technologies by publicly-owned companies: Approaches, drivers and obstacles among Swedish municipal companies, European Planning Studies, 2016. 24(12), pp.2175-2196.

European Planning Studies is available online at informaworldTM:

http://dx.doi.org/10.1080/09654313.2016.1251881

Copyright: Taylor \& Francis (Routledge): SSH Titles

http://www.routledge.com/

Postprint available at: Linköping University Electronic Press

http://urn.kb.se/resolve?urn=urn:nbn:se:liu:diva-133042 


\title{
Export of environmental technologies by publicly-owned companies:
}

Approaches, drivers and obstacles among Swedish municipal companies

\author{
Wisdom Kanda*, Olof Hjelm, Kajsa Kairento and Marcus Nygårds \\ Environmental Technology and Management, Department of Management and Engineering, \\ Linköping University, SE-581 83 Linköping, Sweden.
}

*Corresponding author: E-mail address: wisdom.kanda@liu.se Tel.: +46 (0)13281696 Email addresses: Olof Hjelm (olof.hjelm@liu.se), Kajsa Kairento (kajsa.kairento@gmail.com), Marcus Nygårds (marny281@student.liu.se)

\begin{abstract}
This article focuses on the export of environmental technology by publicly-owned companies. The export of such technologies has the potential to contribute to economic competitiveness and environmental sustainability. However, research on this emerging topic has so far largely focused on privately-owned SMEs compared to publicly-owned companies. Using interviews with twelve Swedish municipally-owned companies which develop such systems and a survey with thirty-six others, we analyse their approaches, drivers for and obstacles to export. These companies use a combination of different approaches such as subsidiaries, independent projects, licensing and private-public partnerships to engage in export. However, in contrast to private companies which are often driven by internal factors such as extra sales, these municipally-owned companies are largely motivated by external factors such as customer requests and opportunities to contribute to environmental sustainability. Furthermore, their main export barriers relate to differences between the business culture and political systems in their home and target markets. Their export experiences are influenced by their municipal ownership, the types of technologies they develop and the institutional contexts within which they operate. This study reveals an actor type struggling to find a balance between domestic obligations and commercialization in international markets.
\end{abstract}

Keywords: publicly-owned companies; global sustainability; large technical systems; technology diffusion; export; waste management

Acknowledgement: This work was supported by Tekniska Verken's Industrial Ecology Research Programme under the BMEX project (Business Models for Market Expansion of Swedish Municipal Companies). We also want to express our sincere gratitude to the interviewees for making time to participate in the interviews. 


\section{Introduction}

A transition to global sustainability requires rapid international diffusion of environmentally relevant technologies (see Rennings, 2014 for a review ). Within this context, the export of environmental technology ${ }^{1}$ is gaining political and research interest (Chiarvesio, Marchi, \& Maria, 2014; Kanda, Hjelm, \& Mejía-Dugand, 2016; Kanda, Sakao, \& Hjelm, 2016). This interest can partly be attributed to contemporary global environmental challenges such as climate change, material and energy resource depletion, biodiversity loss and also the economic opportunities these environmental challenges represent for businesses. These contemporary environmental challenges present opportunities to explore new global markets, including the ability to create win-win situations for economic competitiveness and environmental sustainability (Boons, Montalvo, Quist, \& Wagner, 2013). Several approaches including export, technology transfer, foreign aid, and the expansion of lead markets are available to exploit the development, diffusion and use of environmental technologies globally. However, export is of particular interest for the diffusion of environmental technologies because of its strategic flexibility to tackle environmental challenges as business opportunities and to develop business models for new and emerging markets (Kanda, 2014).

In the academic discourse, research on the export of environmental technologies is still emerging. However, there are several previous literatures on technology export in general and also on environmental technology diffusion in particular. Examples of such previous research relevant for this article include export capabilities among cleantech SMEs (Frankelius, Hultman, Linton, Johanzon, \& Gunnarsson, 2011), internationalization and the propensity to develop eco-innovations (Chiarvesio et al., 2014), governmental initiatives to promote environmental technology export (Kanda, Hjelm, \& Mejía-Dugand, 2015) and components of business concepts for the diffusion of environmental technologies (Kanda, Sakao, \& Hjelm, 2015). Other studies focus on the factors governing the environmental technology diffusion mechanism in general (Kemp \& Volpi, 2008), factors determining the technology adoption at the firm level (del Río González, 2009), and factors governing their diffusion in specific contexts e.g. megacities (Mejía-Dugand, 2013), or in a particular industrial sector (Antonio Belso-Martínez, 2006; Pablo del Río González, 2005). These previous studies have largely but not exclusively focused on environmental technologies in the form of products and services often in the business-to-business and business-toconsumer context.

However, in practise, there are other types of firms actively involved in the environmental technology sector in several countries (see WWF, 2014). Publicly-owned companies have a long historic track record in many countries worldwide for engaging with environmental technologies to provide utilities for their inhabitants. For example, publicly-owned companies are responsible for producing energy for transportation and drinking water in

\footnotetext{
${ }^{1}$ See Section 2.1 for a definition of the term "environmental technology" used in this article.
} 
Canada, electricity generation in New Zealand, solid waste management in Botswana, and electricity, telephony, drinking water and sewage treatment in Colombia (see for e.g. cases in Argento, Culasso, \& Truant, 2016; Furlong, 2016; Mejía-Dugand, 2015b; Taye, Kanda, Krook, \& Lindahl, 2014). In countries like Sweden, municipalities have long been responsible for district heating, waste management, water supply and renewable energy for transportation. As a result many cities and municipalities have established companies which have over the years developed and refined their expertise on environmental technology systems for the provision of such utilities (Kairento \& Nygårds, 2014). Similarly, a few large sized private companies such as E.ON and Veolia develop and operate such environmental technology systems in different countries.

However, such publicly-owned utility companies focused on developing and implementing environmental technology systems are yet to be researched contributively to the academic literature on environmental technology export. We however acknowledge relevant discussions in recent studies on commercialization and internationalization of publiclyowned utility companies even though they devote no particular attention to environmental technologies (see e.g. Argento et al., 2016; Furlong, 2016). With globalization inducing fierce competition on local markets and pressing global environmental challenges, there are increasing trends towards interest in export by publicly-owned companies in general. Furthermore, their owner cities have come to the realization that, export markets represent new opportunities for them to further expand their businesses, gain extra revenue and also generate welfare for their citizens (Mejía-Dugand, 2015a). Analysing such publicly-owned companies holds potentially new scientific insights on the export of environmental technologies because such companies often operate under different ownership, stakeholder and institutional conditions, and business logics, compared to private companies (see Argento et al., 2016; Boon et al., 2013).

Departing from this background, the aim of this article is to analyse the approaches, drivers for and obstacles to the export of environmental technology systems by publicly-owned companies. This aim is supported by three research questions:

- How do publicly-owned companies export environmental technologies?

- What are the drivers for the export of environmental technologies by publicly-owned companies?

- What are the obstacles to the export of environmental technologies by publiclyowned companies?

Drivers for export as defined by Leonidou, Katsikeas, Palihawadana, and Spyropoulou (2007) relate to all factors triggering the decision of the firm to initiate and develop export activities and can be both internal and external, of either a proactive or reactive nature. Export obstacles can be defined as internal and external factors that discourage companies from starting to export or which hinder its existing export (Suarez-Ortega, 2003). 
To address the aim and research questions, we investigate cases from Swedish municipallyowned utility companies. Municipally-owned companies in this study refer to companies fully owned by one or several municipalities. Swedish municipally-owned companies are interesting cases for our research questions for several reasons. First, these companies have been at the forefront in the development of environmental technology systems in Sweden since the 1970s, suggesting accumulated expertise in this sector. Second, there is widespread interest to engage in commercialization and internationalization activities among several Swedish municipalities which offers the opportunity to learn from both successful and failed cases. Last but not the least, the cases offer the researchers proximity for rich empirical data gathering through face-to-face interviews, study visits and access to company documentation which could otherwise be restricted in certain contexts.

To operationalize the aim and research questions, we begin Section 2 by reviewing some literature on environmental technologies to particularly highlight their specific attributes which influence their export. Furthermore, we review literature on basic organizational forms of export and their core features. We continue Section 2 by discussing export by public-owned companies including their particular attributes as reported in previous literature. Section 3 covers the method used to collect and analyse the empirical data. Our findings are presented in Section 4 while in Section 5, we analyse the results with the help of the reviewed literature presented in Section 2. We conclude in Section 6 and discuss further research possibilities.

\section{Theoretical background}

In this section, we define the term "environmental technology" in the context of this article and highlight its particular characteristics that can enhance and/hinder their export. We then review some basic organizational forms of export market entry from the international marketing and export management literature. Furthermore, we review literature on factors which influence the experiences (drivers and obstacles) of publicly-owned companies in export. The purpose of this section is to serve as a basis for the empirical data collection and analysis.

\subsection{Environmental technology systems}

The term "environmental technology" has different definitions and associated meanings throughout literature (see Guziana, 2011). For example, there are broad understandings to the term as presented by Carrillo-Hermosilla, Del Río, and Könnölä (2010 p.1075) as "an innovation that improves environmental performance." Kemp (1997 p.11) offers a bit more detail by defining environmental technologies as each "technique, process or product which conserves or restores environmental qualities". In the public domain, the European Commision (2004 p.2) defines environmental technologies as: "all technologies whose use is less environmentally harmful than relevant alternatives. They encompass technologies and processes to manage pollution (e.g. air pollution control, waste management), less polluting 
and less resource-intensive products and services and ways to manage resources more efficiently (e.g. water supply, energy-saving technologies)". In this article, we adopt the definition presented by the Swedish Ministry of the Environment (2005): - goods, systems, processes and services that offer clear environmental advantages in relation to existing or alternative solutions, seen from a lifecycle perspective. This definition is adopted because it has a broad and inclusive scope, is familiar to our interviewees and thus served as a common departing point during our interviews. However like many terminologies, "environmental technology" is a highly contested term in the academic discourse. For example, the term suggests the realization of environmental benefits which is in itself difficult to prove in certain circumstances but to complicate matters; environmental intentions (and even nonintentions) have also been argued as equally important components of the term(see CarrilloHermosilla et al., 2010). And as Markusson (2011) puts it, the term can be deceiving and may even express environmental intentions where there are none. The relative aspect of environmental benefits also means that, certain technologies can always be argued to be environmental beneficial in comparison to environmentally "worse" alternatives which can perform a similar function. For example waste incineration can generally be considered to be environmentally beneficial compared to landfilling even though incineration has in certain instances been attributed with the release of toxic dioxins, and encouraging more consumption instead of waste avoidance and reuse (see Corvellec, Zapata Campos, \& Zapata, 2013).

This article focuses on companies with competences in the development and operation of environmental technology systems such as waste management, renewable energy and district heating systems. These systems encompass capital intensive infrastructure with a broad range of technical components, as well as associated actors and institutions (Markard \& Truffer, 2006). Such large technical systems are closely interrelated with the associated actors, networks and institutions, and thus changes in one of the systems' components induce changes in the other system components as well. Their characteristics do not only dwell on the technical components but also on non-technical aspects such as regulations, norms, user behaviour and networks. These systems are of particular interest when it comes to sustainability discussions because of their combination of both technical and nontechnical dimensions. This includes both hardware (e.g. products, tools, and machines) and software (e.g. procedures/processes and digital protocols) that are used to solve real world problems. In addition, they cover knowledge either in general terms or embodied with the physical artefacts relevant for in designing, implementing, operating and maintaining such systems. The consideration of both technical and non-technical dimensions characteristic during the development, implementation and use of large scale technical systems is expected to lead to system-wide environmental improvements compared to incremental environmental benefits associated to changes in products and services alone (OECD, 2009).

More so, the specific characteristics of such environmental technology systems are expected to influence their export. Kanda, Sakao, et al. (2016) studied the export of waste 
management, renewable energy, and district heating systems and extracted certain attributes which influence their export. These identified characteristics relate their complexity - different technical components, actors, networks and institutions. The capitalintensive nature of such systems also places a heavy weight on financing when it comes to their export. Furthermore, such environmental technology systems need adaptability to meet the demands of different types of markets even in foreign countries. For example there exist different types of markets around municipal solid waste incineration with energy recovery - waste-as-raw- material market, commercial market for heat and electricity, and technical market for different waste treatment options. Also the combination of technological and non-technological aspects in such systems requires for considerations of values, behaviours, laws and regulations in foreign markets by exporters. Similarities in structure and characteristics can be observed in railway systems, telecommunication networks and military defence systems.

\subsection{Export market entry modes}

The international marketing and export management literature is extant with numerous contributions on the choice of foreign market entry strategy (Canabal \& White, 2008). These contributions have employed different theoretical departure points to analyse the strategies and operational choices of companies. Among these theoretical approaches include transaction cost theory which emphasizes the need for firms to create governance structures that costs and inefficiencies associated with export; the eclectic paradigm based on the notion that entry mode consists of three factors: ownership, location and internalization; cultural distance; control and internationalization (see Canabal \& White, 2008 for a review ). The internationalization literature has been particularly interested in among other questions, how firms internationalize. Over the years, there have been different contributions from the stages view where internationalization is a process of increasing linear commit to foreign markets based on increasing experiential knowledge (Johanson \& Vahlne, 1997). More recent contributions have demonstrated the importance of business networks with customers, distributors, suppliers, competitors and government in internationalization (Johanson \& Vahlne, 2009).

An international market entry mode is an institutional arrangement which facilitates the entry of a company's offerings into a foreign market (Albaum, Albaum, \& Duerr, 2008).This represents a crucial strategic decision for companies since it can be a source of competitive advantage or missed opportunities (Osland, Taylor, \& Zou, 2001). In principle, a company can export either directly and/or indirectly. Four major alternatives of structural arrangements are available for foreign market entry - direct sales, licensing, joint ventures, and whollyowned subsidiaries (Osland et al., 2001). In direct sales, the company's final or intermediate product is manufactured in the home market and subsequently transferred to the target customers. Licensing involves a contractual agreement with a company which is active on international markets to use some or all the exporting companies' patents, trademarks, name, technology, and business methods at an agreed fee. Joint ventures and wholly-owned 
subsidiaries could either be located in the home or target market and are established with the ambition to engage in export activities on behalf of the parent company. Each partner contributes to the venture financially, through technology, and/or human resources. These modes of entry can be differentiated according to at least three categories: quantity of resource commitment required; amount of control, and level of technology risk. In practice, there are a host of target market factors and also within company factors that affect the choice of entry mode.

When it comes to the dynamics of publicly-owned companies in export, previous research has shown that publicly-owned companies do not necessarily fit the typical description of international activities performed by private multinational companies. Public-owned enterprises often operate with a different logic from entirely private companies mostly because of their ownership, which influences their behaviour and strategies (Estrin, 2012). A company's choices in relation to its export activities depend upon the obstacles it faces, as well as drivers which make export an attractive choice. Private companies often strive to create value for shareholders measured in cash flow and revenue, while public-owned enterprises have a distinctively different set of stakeholders (political representatives, and indirectly the local citizens) who could have completely different interests and measures of shareholder value. Thus, goals such as environmental benefits, creating employment, relationships with certain cities and municipalities, access to new technology and organizational knowledge could be of more interest for such publicly-owned companies (Estrin, 2012) and often might not explicitly stipulate financial goals of profitability. On the other hand, the institutional contexts within which such publicly-owned companies operate is capable of generating ambiguity which can hamper as well in certain instances enhance their exports (Argento et al., 2016). In the broader European context, various national laws and EU directives and regulations limit the businesses and geographical areas across which publicly-owned companies can operate on the premises of market distorting and unfair competition between private and public companies. This continues to impose some constraints on the economic and legal possibilities of such publicly-owned companies which indirectly affect their daily operations and investment opportunities such as export (see Argento et al., 2016). For example, the municipalities' law in Sweden stipulates the home geographical area and the interests of its citizens as the main focus for municipal companies with amendments in 2009 enabling the ability to conduct commercial activities outside its owner municipality which must be profitable with low risk and secured by some guarantee or insurance (SFS, 2009).

Furthermore, the public ownership of such companies can create certain advantages from city-to-city relationships such as risk mitigation, information sharing and access to wider markets which are relevant for the diffusion of environmental technologies (Mejía-Dugand, Kanda, \& Hjelm, 2016). Public ownership sometimes induces both market and non-market goals which could sometimes be conflicting in export. For example, discrepancies may emerge between the company executives on one hand and other stakeholders such as the political owners and citizens on the other hand (Estrin, 2012). The company management may for example have a different degree of entrepreneurship and market orientation than the owners and such a situation can be a barrier to export. Thus an interplay between of internal and external factors 
shape the strategies and operational choices of publicly owned companies in commercialization and international markets.

\section{Method}

This section of the articles describes the logic employed to select the studied companies, how the empirical data were collected and analysed in this article.

\subsection{Collecting empirical data}

The empirical data collection consisted of four main steps which are summarised in Figure 1 below.

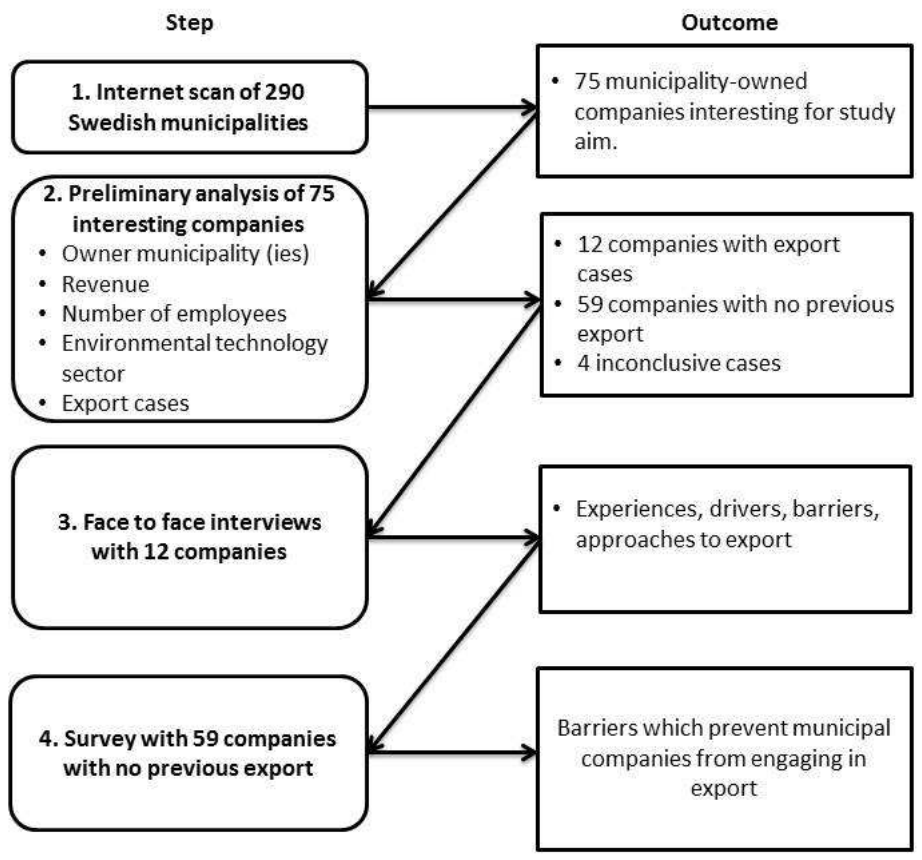

Figure 1: Main steps in the empirical data collection

The empirical data collection began with a review of public information to identify relevant cases of municipality-owned companies for our research aim. With 290 municipalities in Sweden, this initial review took the form of an internet scan focused on finding municipallyowned companies from the entire Sweden which develop, operate and export large scale environmental technology systems. Due to the practicality of handling the volume of information, the scan focused on the larger sized municipalities which often own such municipal companies. The internet scan covered company websites, industry organizations publications and websites with a total outcome of 75 municipality-owned companies fitting the aims of the study (as shown in Figure 1). These 75 municipality-owned companies are owned by a total of about 100 Swedish municipalities with about half the entire population of Sweden. For each of the 75 companies detected, information on company owner municipality(ies), revenue, number of employees (as of 2012), environmental technology 
sector, cases of export activities were recorded in order to guide the selection of interesting cases for deeper analysis. From this preliminary analysis, we detected twelve municipalityowned companies with export activities for deeper analysis (see Figure 1 above).

For empirical data collection from the twelve identified cases, we developed a semistructured qualitative interview guide for face-to-face interviews. Qualitative data enables us to capture the nature of things and refers to meanings, descriptions, and characteristics which often are difficult to capture with other kinds of data (see Berg \& Lune, 2004). The interviews lasted between sixty and ninety minutes and were recorded and transcribed for further processing. The main discussion themes were on the export activities that have taken place, how these activities were undertaken, their outcomes and main challenges. With these themes questions, it was important to select qualified respondents, thus chief executive officers or top-level management responsible for company strategies and export activities were selected for interviews in all the twelve companies, as shown in Table 1 below.

In addition to the twelve exporting companies (see Table 1), the background literature informed us about the existence of export barriers which deter non-exporters from commencing export. This group of companies are also relevant to uncover particularly when it comes to encouraging non-exporters to export (Kanda, Mejía-Dugand, \& Hjelm, 2013). From our initial scan which resulted in 75 municipality-owned companies, information on 59 of the companies indicated no previous or ongoing export activities. To uncover barriers which prevented such companies from engaging in export, an online survey to the chief executive officers and members from the top management of those companies was conducted with a response rate of $61 \%$ (36 respondents out of 59 ).

Table 1: Overview of selected case companies and interviewee(s)

<<For Table 1, see appendix>>

Note that the list of target markets is not exhaustive but rather those recognised by the interviewees as their main targets including both realised and attempted projects. 1 SEK ranged between 0.11 EUR (January) and 0.12 EUR (December) 2012.

\subsection{Analysing the empirical data}

Since information in the interview transcripts were not always explicit in relation to drivers for, obstacles to and approaches for export, keywords in combination with thematic analysis were used to develop insights relevant for our research questions. The keywords were informed by the reviewed literature and the words used by our respondents during the interviews. Examples of keywords include for export drivers (gains, results, expectations) and obstacles to export (challenges, refrain, discussing). Even though these keywords relate to approaches, drivers for and obstacles to export, it should be highlighted that in certain cases empirical information could not fit into one particular category and had to be interpreted 
based on the researchers experience on the subject. All transcripts were later checked by the interviewees for the accuracy of the content in reflecting their views.

The empirical data was collected to analyse the approaches, drivers and obstacles to export of environmental technologies among publicly owned companies. Thus, a thematic approach was used (see Stebbins, 2001; Wolcott, 2008) to categorise the interview transcripts iteratively into emerging themes and patterns. This was undertaken by the two researchers who conducted the interviews to enhance content validity. A third researcher who supervised the empirical data collection process also checked the interview transcripts and emerging themes for coherence. Following this, the approaches to export were selfrevealing from the interview transcripts and were grouped together under the various export market entry modes identified in our literature review. Each mentioned driver and obstacle (barrier and challenge) to export was also numerically counted to record the number of times it was mentioned during the interviews and also as an indication of its frequency among exporters. Finally, the theoretical background presented in Section 2 was then used to analyse and give potential explanations as to why publicly-owned companies experience the different kinds of approaches, drivers and obstacles which were identified from the interviews. Conclusions are drawn from this with implications and further research possibilities. 


\section{Results}

Following our research questions, the approaches, drivers for and obstacles to export among the studies municipally-owned companies are presented below.

\subsection{Approaches to export}

The studied municipality-owned companies use a variety of approaches to export. We have categorised these into at least 5 main approaches as: (i) Subsidiary approach (ii) Independent export projects (iii) Symbiotic private-public partnerships (iv) Licensing (v) Privatisation.

\section{(i) Subsidiary approach}

Four of the interviewed companies (Borås Energi och Miljö, Sysav, Tekniska Verken i Linköping, Umeå Energi) have established independent subsidiaries each to engage in export activities based on the competence in the parent municipal company. Tekniska Verken decided in 2008 to establish a subsidiary, Usitall (hibernating as of 2015) which was responsible for export on waste-to-energy systems targeting Eastern Europe and especially Romania. The business model of this subsidiary was to develop waste-to-energy projects, and secure waste certificates and commercial markets for the material and energy recovered from the waste. The company would then find a potential buyer for the project before the construction phase and exist. The Borås Energi och Miljö is part of a constellation made up of the University of Borås and SP Technical Research Institute of Sweden. Together they form an initiative - Waste Recovery Borås - and focus on sustainable waste management in Indonesia and Vietnam. Their export activities so far include a trainee program on sustainable waste management for foreign companies and politicians and feasibility studies in foreign markets on renewable waste management solutions such as biogas.

\section{(ii) Independent export projects}

Another approach to export is to engage in independent projects abroad with some dedicated employees from the parent municipal company. For example Borlänge Energi has had several projects within waste water treatment systems, waste-to-energy solutions, city planning, and establishing environmental technology centres in countries such as Moldova, Chile and China. Other such independent projects include waste management projects by Eskilstuna Energi och Miljö in India, education and training for professionals on waste management in Poland by Gästrike Återvinnare. Similarly, Sysav has had a number of independent waste management consultancy projects regarding feasibility solutions abroad including solid waste and wastewater management, in Canada and waste management planning for the greater region of Dublin. Such independent export projects can be facilitated by each municipality's international city network e.g. the provision of recycling stations in Namibia and infrastructure projects in the Chinese city of Tang by Sysav, and 
design and feasibility studies for a transfer and recycling center in Gaborone, Botswana by VafabMiljö.

\section{(iii) Symbiotic private-public partnership}

Exporting by acting as a partner to private companies is also a common approach used by Swedish municipality-owned companies. Borlänge Energi, C4 Energi AB, Eskilstuna Energi och Miljö, Kraftringen $A B$, Renova and Öresundskraft $A B$ have all been involved in export projects as partners to private companies. This partnership is symbiotic in the sense that the two partnering organizations are different at least in terms of ownership but often intend to benefit from the competence of each other. These partnerships have involved both individuals from the municipal company with certain competencies or the municipality company as a whole with collaborations with public-owned organization such as the Swedish export promotion agency (Business Sweden) and also private consultants.

\section{(iv) Licensing}

In this approach to market expansion, the municipality-owned company licences its technology to another firm which is active in international markets. Through this agreement, the municipal company earns a fraction of the total revenue generated by the internationally active company. This is an indirect way to entering international markets and the municipal company does no active marketing or contacts with end-users. A licensing agreement between Svensk Biogas (a subsidiary of Tekniska Verken I Linköping) and the private company Kemira to sell biogas process optimization additives is an example of such an approach.

\section{(v) Privatisation}

In this approach, a completely private company emerges as a spin- off from activities of the parent company. This private company is formed from the competence of the parent company and emerge either in a planned or unplanned way (through conflicts of interest, breakaways etc.). Some employees of the parent company end up with the new and completely private company. In this approach, the focus of this new private entity is on foreign markets from the start with active marketing and export strategies. Financial inflow is completely dependent on the activities of this company abroad and possible contributions from the owners and private venture capitalist. For example, Swedish Biogas International emerged from Tekniska Verken AB I Linköping and has been active on export markets from the start.

\subsection{Drivers for export}

Drivers for export relate both to reasons to participate in export as well as perceived gains from export. The different incentives and their appearance frequency are presented in Figure 2 below. Most companies mentioned more than one driver and thus the sum of the frequencies is more than the total number of cases. 


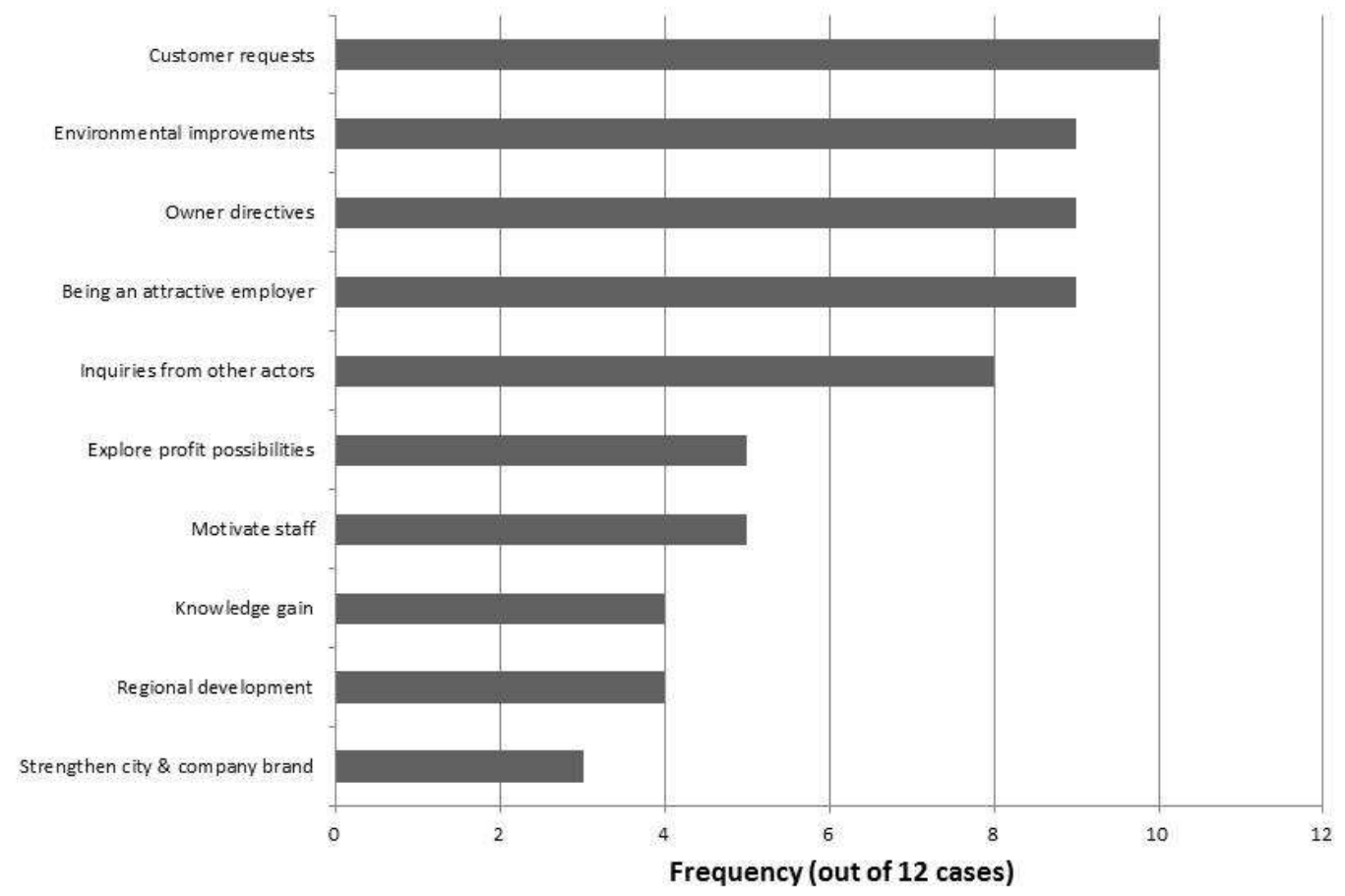

Figure 2: Frequency of mentioned drivers for export

A strong driver for participating in export by the studied companies is customer requests as indicated in Figure 2 above. Most often, a foreign delegation visits a Swedish municipality and sees the potential use of one or a group of their technologies for waste management, renewable energy generation, or district heating and makes a request to the municipality for assistance with developing and operating a similar environmental technology system.

Making a contribution to global environmental improvement was the second highest mentioned incentive for participating in export (8 out of 12 cases, see Figure 2). Many of these municipality-owned companies indicated the global nature of environmental challenges such as climate change and resource depletion as important incentives for extending their environmental technology systems into foreign markets where they might even be of more importance. And as the interviewee from Borlänge Energi pointed out, Swedish environmental technology systems have been developed and refined over a long period of time and could potentially deliver more radical environmental improvements in some markets than incremental improvements in their local municipalities (Interview, Borlänge Energi - head of international projects). 
Internal factors for engaging in export include organizational improvements such as becoming an attractive employer, motivating staff and knowledge gain. Many of the municipality-owned companies indicated that export projects made their companies attractive employers, particularly for recent graduates and young people. As mentioned by the CEO of VafabMiljö, they would rather offer their employees export projects than see them switch to private companies to feel stimulated (Interview, VafabMiljö - Chief Executive Officer). Another organisational improvement driver relates to potential knowledge gain from export. It is expected that through exports, employees could develop their competence and knowledge regarding new technologies and also working conditions in foreign markets. For example, VafabMiljö indicated that many of the waste treatment plants in Sweden were built some time ago but international customers are interested in the state-of-the art technologies which give the municipal company and its employees the opportunity to develop the knowledge and competence needed for operating such technologies in new markets (Interview, VafabMiljö - Chief Executive Officer).

Other incentives to engage in export relate to business goals such as to strengthen the company and city brand, contributing to regional development by creating export opportunities for local companies and to explore opportunities for extra income. For example, interviewees from Sysav, Tekniska Verken AB I Linköping, Gästrike Återvinnare and Öresundskraft, Renova explicitly mentioned the possibilities for profit and growth as a driver for engaging in export. However, the interviewee from Umeå Energi considered their export activities as a way of creating business opportunities abroad for local companies because of their networks with different cities and municipalities and their ability to enter certain markets which are not readily open to the private sector, something interviewees from VafabMiljö and Sysav reiterated through their ability to bring local companies along in their export activities.

\subsection{Obstacles to export}

The obstacles to export from the studied municipal companies relate both to what companies perceive as challenging in exporting as well as what prevents some companies from initiating export. The different reasons and their frequency of being mentioned by the different municipality companies are presented in Figure 3 below. Most companies mentioned more than one barrier and thus the sum of the frequencies is more than the total number of cases. 


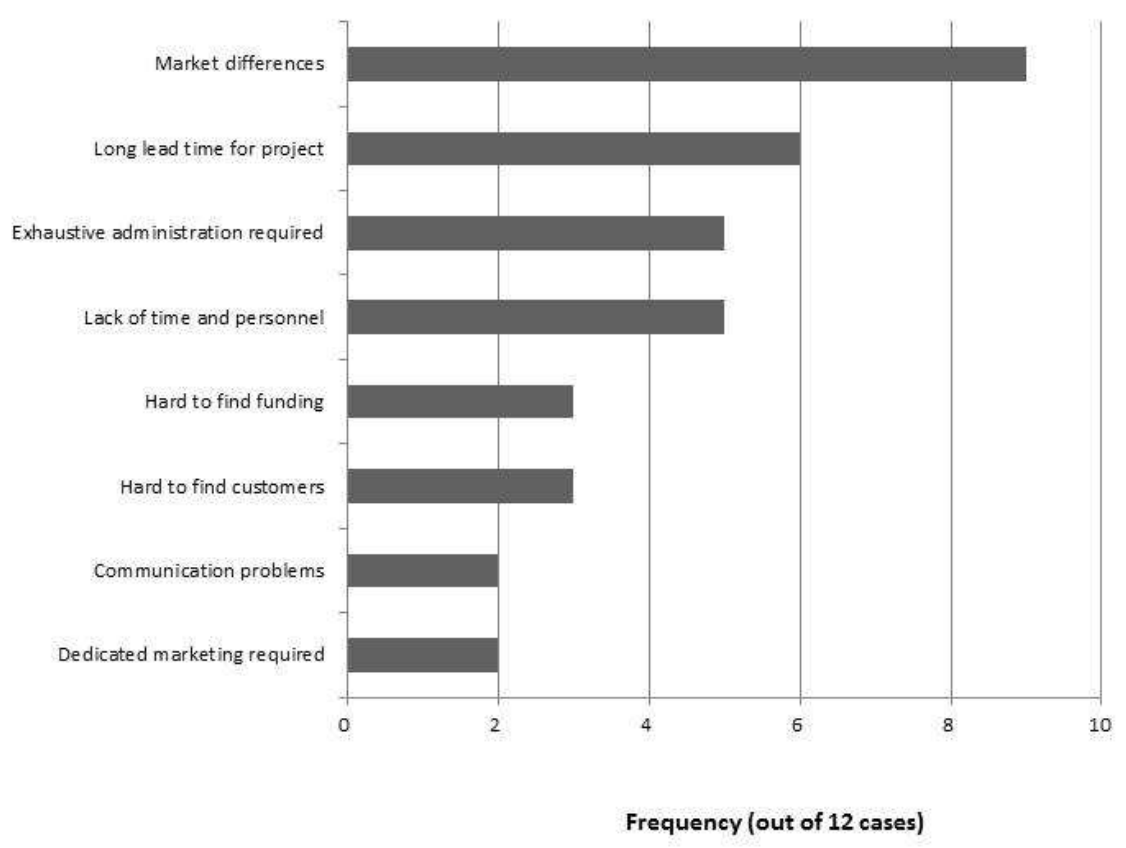

Figure 3: Frequency of mentioned challenges to export

Export barriers relating to market differences include differences in business culture and political systems between the Swedish municipality and their foreign markets. As shown in Figure 3 above, market differences dominate the export barriers. The differences in business culture relate to organizational structure which with some potential customers is very hierarchical meaning that decisions about export projects are slow, resulting in a long lead time from first contacts to project realisation. This long lead time also relates to the particular characteristics of the environmental technology systems which often requires agreement with several technicians, actors and institutions which can be time consuming taking up to seven years to secure all contracts a period within which market signals and political powers might have changed (Interview, Usitall AB). There is also political resistance to the particular large scale environmental technology system in certain markets. For example Sysav could not develop a proposed waste incineration facility in Toronto, Canada because the major had made a political pledge not to allow any such incineration projects out of widespread fear for dioxins (Interview, Sysav).

The lack of resources such as time, personnel and financing to engage in export activities is a well-known export barrier. In some instances, export managers had observed that, various line managers within the municipal company are not very willing to lend out personnel with certain competencies for export activities since that could disturb the local operations of the 
company. For example, the CEO of Sysav pointed out that the lack of personnel was one of their main barriers to export, with many of the companies reiterating that their local responsibility always comes first, which hinders how much export they can engage in (Interviews, Renova, Umeå Energi). Sometimes, the large scale attribute of such export projects means that financing has to be sought from international organizations such as SIDA (The Swedish International Development Cooperation Agency), the European Union or the World Bank. However, applying for and administering such funding processes can be timeconsuming, which could hinder such export projects from being initiated in the first place.

Many of the interviewed municipal companies discussed that, even though the potential customers recognize the need for their solutions, it is often difficult to get their financial commitment. They attribute this to several reasons, including the fact that many cities and municipalities face a mix of challenges of which one of them could be environmental problems. Thus, these cities and municipalities with often limited budgets tend to prioritise challenges such a as health care, education and employment over for example waste management systems. In addition, some cities and municipalities have a lax enforcement of environmental regulations which means that investing in systems for controlling air pollution, or recycling waste instead of landfilling is not so prioritised.

From the survey, data was collected on barriers which prevented companies from engaging in export. Institutional barriers relate to how the political owners of municipal companies regard export activities. In some instances some companies have referred to the municipalities' regulations as not supporting the export of environmental technologies because of the risk involved in such export projects. Other barriers which prevent the commencement of export activities include lack of resources, reorganization and priorities on local markets, not-permitted by law, not supported by owners, overwhelming market activities required, and lack of incentives.

\section{Discussions}

In this section, we discuss our findings presented above using insights from the literature reviewed in the background section.

\subsection{Approaches to export}

There are no established approaches to export among the studied companies but rather combinations of different approaches to export are being explored. A plausible explanation for this observation could be linked to the different municipalities which own these companies and their related stakeholders who can require certain obligations and expectation from them. And thus in the face of such obligations and expectations, these companies could employ approaches which are cost efficient, enable them to meet their international expectations as well as local obligations with the resources they have. Furthermore, many of these companies have in the past focused on their local customers 
with export being an emerging phenomenon being explored in the recent decades which means that there are not many established approaches to imitate. With a subsidiary approach, the parent company has the freedom to focus on its home municipal responsibilities whiles the subsidiary engages with international markets. However, the subsidiary can suffer from control and dependence on its parent company for human, financial and technical resources to engage in export. The subsidiary approach is attractive for companies where the parent company has been more engaging and aggressive with international activities. However, the resource commitments required and the relatively long lead time needed to develop such environmental technology system project means that stakeholder expectations of generating financial gains from international markets might be delayed or even not realised leading to withdrawal of stakeholder support and a clash between business interests and stakeholder expectations. On the other hand, independent export projects run by the parent municipal company represent the most common export approach. Such export projects are however often financed by aid organizations such as SIDA, the EU and the World Bank. This relates to the characteristic capital-intensive nature of such environmental technology systems which often require external funding. This independent export projects seem popular among these companies because they often do not require much human and financial resource commitment on their part than for a few man hours and travel costs. This gives them the freedom to meet expectations from their stakeholders to engage in international activities while focusing and committing most of their resources to their local market (cf: Osland et al., 2001).This approach of minimizing minimalistic resource commitment to international activities attracts municipally owned company with no keen interest in commercial gains from international markets but wanting to meet other stakeholder expectations - establishing a fine balance between business interests and stakeholder expectations (Argento et al., 2016).

Other export approaches include symbiotic partnerships with other exporters. The purpose of these kinds of partnerships is to depend on each other's competence and gain synergies which are otherwise impossible to achieve alone. The other partners could be in need of competence which the municipal company can deliver. Depending on the other partner, the collaborative incentives could differ from extra income, to developing networks, and long term collaboration partners. These partners could be in the home or target market and range from private consultants, technology companies to cities. However, a resounding characteristic of such partnerships for export is that the, market exposure and risk for the municipal company is reduced. This reduced risk exposure position suits the legal obligations often placed on these companies and also allows them to commit more resources to their home market. The amount of control each partner has is related to its contribution to the partnership. Other one-off approaches to export included licencing agreements and complete privatisation of the competence from the municipal company. In licencing and privatisation approaches, the desire for business growth is explicit from the start with proactive marketing, publicity and sales promotion which are not typical in the other 
approaches. And more so, municipal company can concentrate on its core activities in both of these approaches to export.

\subsection{Drivers for export}

It could be seen clearly from the results that the dominating incentives for export was reactive-i.e. a response to unsolicited customer requests (cf. Figure 1). These customer requests are often initiated by high-level governmental delegations and political actors from different cities and municipalities around the world visiting Sweden. Unsolicited orders from potential customers have been highlighted in the literature as one of the most important drivers for export (Czinkota \& Ronkainen, 2006). This reactive approach to export observed among the studied companies is not surprising since these companies have a history of prioritising their local responsibilities. This reactive attitude to export has been observed in small companies (Leonidou et al., 2007) as well as in different countries (Czinkota \& Ronkainen, 2006). This reliance on customer requests could be motivated by the institutional and economic systems in Swedish municipalities which puts some municipal companies in a strong almost monopolistic market position (see Corvellec \& Bramryd, 2012).. Another resounding export incentive indicates the desire for organizational improvement. Many of the companies saw export activities as an opportunity to make themselves an attractive employer and also retain young and recent graduates. This resource-driven incentive relates to the potential knowledge and competence from international networks, city-to-city collaborations and export projects which in many ways contrast the typical financial resource incentive reported for private companies (Leonidou et al., 2007).

An incentive not often encountered for private companies is the desire by to make a contribution to global environmental improvements. This was the second most prominent reason for engaging in export (cf. Figure 1). The desire for environmental improvements could be a unique attribute of such companies because of their long historic experience, the potential for radical environmental improvement in foreign markets and also their stakeholders' objectives. Their familiarity with tackling environmental problems from local inhabitants and coupled with numerous international visits and requests such companies receive could strengthen the desire for such environmental contributions. For municipal companies, their stakeholders' values could include environmental performance such as reducing green-house gas emissions, opportunities that are increasingly global. Other nontypical export incentives relate to strengthening the city and company brand and contributing to regional development which are often stimulated by their political owners potentially contributing to export (Mejía-Dugand et al., 2016).

Nonetheless, the opportunity for business growth also appears as an export incentive even though not as pronounced as literature reports for private firms who report their highest motivations potential for extra sales profits and growth (cf: Leonidou et al., 2007). Many of the studied companies just indicated the desire for their costs to be covered in the export activities rather than to make profit. This could relate to the fact that many of the municipal 
companies operate on a local market protected by institutional and economic conditions which gives them the financial independence they need than to operate on export markets. Empirical evidence also suggests the importance of internal incentives for engaging in export. These incentives could relate to the company as a whole or to individual attributes of its employees. On the organizational level such internal incentives are manifested through being an attractive employer and motivating the staff through international activities. More so, companies with highly committed managers who have an international mind-set are more likely to initiate export activities. Such international mind-set can develop from several experiences such as previous positive experience with export, having spent time in a foreign country, and having gained professional experience within international organisations (Leonidou et al., 2007).

\subsection{Barriers to export}

It is apparent from our findings that market differences in business and political systems constitute a significant barrier for these companies. They can be constraints related to attitude, structure or operational issues that deter a company from initiating, developing or sustaining international operations (Smith, Gregoire, \& Lu, 2006). This is a significant barrier both in the direction that some municipal companies and their employees lack knowledge and understanding of how things work in foreign markets, an essential part of firms export performance (see Díez-Vial \& Fernández-Olmos, 2014) and also some actual market differences mean that things do not progress as they would in their local markets, making lead times for projects unnecessarily long. The political system including environmental regulations as indicated by (Pablo del Río González, 2009; Kanda, Sakao, et al., 2015) plays a significant role in the adoption of environmental technologies. And in particular, some environmental technology types (such as end-of-pipe solutions) need effective regulations for their adoption. In situations of lax implementation of environmental regulations, municipal companies face financially uncommitted customers.

Another pronounced export barrier relates to the companies' lack of resources to actively engage in export and its related activities. The smaller sized municipal companies expressed stronger resource constrains compared to the larger sized companies, which is supported by findings from Smith et al. (2006), who conclude that company size indicates to some extent the type of resource barriers experienced in export, risk-tolerance and also how strongly those barriers are felt . In this case, the issue of resource constraints is also rooted in the company ownership which means that they often prioritise their local operations over committing resources to export.

The municipal ownership structure of these companies also induces some institutional barriers. The political owners and the management of the company could have different entrepreneurial ambitions which often results in conflicting export signals to the municipal company, for example break-off or privatisation. On the other hand, the institutional 
protection given to the company on the local market can induce decreased interests in international markets.

\section{Conclusions}

This article contributes to the literature by addressing three research questions regarding the approaches, drivers for and obstacles to the export of environmental technology systems among publicly owned companies.

Regarding approaches to export, the studied municipally-owned companies use a combination of different strategies. The different strategies are largely influenced by the municipal ownership and the stakeholder obligations it imposes, the particular characteristics of the environmental technology systems and level of export ambition of the municipal company. Drivers for municipal companies to engage in export are largely external even though they have an underlining internal drive. This relates to customer requests, owner directives and the desire to contribute to global environmental improvement. These export incentives are different from the incentives typically reported for privately owned companies. Other internal incentives such as business growth opportunities are identified but not as strong as for private companies. This can largely be attributed to the key stakeholders of publicly-owned companies such as politicians and citizens whose immediate interest might not be financial gains but the longevity of the company in meeting its local obligations. The most pronounced export barriers relate to the differences in business culture and political systems between the home and foreign markets. In the face of such differences publicly-owned companies face uncommitted customers, political opposition and long lead times to project realisation. Such an obstacle is not exclusive to publicly-owned companies but since they often engage in such export activities as secondary compared to their domestic obligations, these obstacles can become insurmountable and often lead to the failure of export projects. Also the large technical systems they develop and the different technical components, actors and institutions means that in international markets such differences can be compounded particularly in non-technological aspects making export even more challenging.

For policy makers, the long historic competence in such publicly-owned companies makes them an important actor in addressing global environmental challenges. At the same time institutional obligations and stakeholder expectations means that, these companies sometimes find themselves with a black hole with no clear signals as to what to do and what not to do regarding export. Based on our conclusions, policy makers could consider redefining the roles of publicly-owned companies in their international activities. For example, such companies could represent a new opportunity for channelling public funds such as aid finance into international projects while collaborating with private companies both home and abroad. It remains the task of researchers to analyse which business constellations could be better suited for publicly-owned companies in the quest for global sustainability. 


\section{References}

Albaum, G. S., Albaum, G., \& Duerr, E. (2008). International marketing and export management: Pearson Education.

Antonio Belso-Martínez, J. (2006). Do industrial districts influence export performance and export intensity? Evidence for Spanish SMEs' internationalization process. European Planning Studies, 14(6), 791-810.

Argento, D., Culasso, F., \& Truant, E. (2016). Competing logics in the expansion of public service corporations. Utilities Policy, 40, 125-133. doi: http://dx.doi.org/10.1016/j.jup.2016.02.007

Berg, B. L., \& Lune, H. (2004). Qualitative research methods for the social sciences (Vol. 5): Pearson Boston.

Boons, F., Montalvo, C., Quist, J., \& Wagner, M. (2013). Sustainable innovation, business models and economic performance: an overview. Journal of Cleaner Production, 45(0), 1-8. doi: http://dx.doi.org/10.1016/j.jclepro.2012.08.013

Canabal, A., \& White, G. O. (2008). Entry mode research: Past and future. International Business Review, 17(3), 267-284.

Carrillo-Hermosilla, J., Del Río, P., \& Könnölä, T. (2010). Diversity of eco-innovations: Reflections from selected case studies. Journal of Cleaner Production, 18(10), 1073-1083.

Chiarvesio, M., Marchi, V. D., \& Maria, E. D. (2014). Environmental Innovations and Internationalization: Theory and Practices. Business strategy and the environment.

Corvellec, H., \& Bramryd, T. (2012). The multiple market-exposure of waste management companies: A case study of two Swedish municipally owned companies. Waste management, 32(9), 1722-1727.

Corvellec, H., Zapata Campos, M. J., \& Zapata, P. (2013). Infrastructures, lock-in, and sustainable urban development: the case of waste incineration in the Göteborg Metropolitan Area. Journal of Cleaner Production, 50, 32-39. doi: http://dx.doi.org/10.1016/j.jclepro.2012.12.009

Czinkota, M., \& Ronkainen, I. (2006). International marketing. Hinsdale: The Dryden Press.

del Río González, P. (2005). Analysing the factors influencing clean technology adoption: a study of the Spanish pulp and paper industry. Business strategy and the environment, 14(1), 20-37.

del Río González, P. (2009). The empirical analysis of the determinants of technologicall change: A research agenda. Journal of ecological economics, 861-878.

Díez-Vial, I., \& Fernández-Olmos, M. (2014). How Do Local Knowledge Spillovers and Experience Affect Export Performance? European Planning Studies, 22(1), 143-163.

The Swedish Ministry of Environment. (2005). Environmental Technology. Retrieved from http://www.government.se/sb/d/5400/a/43595.

Estrin, S. (2012). The Internationalization of State Owned Enterprises: The Impact of Political Economy and Institutions. London Business School.

European Commision. (2004). Stimulating technologies for sustainable development: an environmental technologies action plan for the European Union. Brussels.

Frankelius, P., Hultman, C., Linton, G., Johanzon, C., \& Gunnarsson, C. (2011). The cleantech mystery: new theoretical model for understanding export capabilities in small and mediumsized innovative cleantech companies.

Furlong, K. (2016). The public shareholder: The commercialization and internationalization of publicly owned utility corporations. Utilities Policy, 40, 104-106.

Guziana, B. (2011). Is the Swedish environmental technology sector 'green'? Journal of Cleaner Production, 19(8), 827-835.

Johanson, J., \& Vahlne, J. E. (1977). The internationalization process of the firm-a model of knowledge development and increasing foreign market commitments. Journal of international business studies, 23-32. 
Johanson, J., \& Vahlne, J. E. (2009). The Uppsala internationalization process model revisited: From liability of foreignness to liability of outsidership. Journal of international business studies, 40(9), 1411-1431.

Kairento, K., \& Nygårds, M. (2014). Export of municipal environmental technology knowledge : An analysis of previous activities and incentives $\langle e m></ e m>$. (Master's degree), Linköping University. Retrieved from http://urn.kb.se/resolve?urn=urn:nbn:se:liu:diva-106307

Kanda, W. (2014). Promotion of Environmental Technology Export : Governmental Initiatives and Business Concepts. Linköping University Electronic Press, Linköping. Retrieved from http://urn.kb.se/resolve?urn=urn:nbn:se:liu:diva-108730

Kanda, W., Hjelm, O., \& Mejía-Dugand, S. (2016). Promoting the export of environmental technologies: An analysis of governmental initiatives from eight countries. Environmental Development, 17, 73-87. doi: http://dx.doi.org/10.1016/j.envdev.2015.09.009

Kanda, W., Mejía-Dugand, S., \& Hjelm, O. (2013). Governmental export promotion initiatives: awareness, participation, and perceived effectiveness among Swedish environmental technology firms. Journal of Cleaner Production(0). doi: http://dx.doi.org/10.1016/j.jclepro.2013.11.013

Kanda, W., Sakao, T., \& Hjelm, O. (2016). Components of business concepts for the diffusion of large scaled environmental technology systems. Journal of Cleaner Production, 128, 156-167.

Kemp, R. (1997). Environmental policy and technical change: Edward Elgar Publishing.

Kemp, R., \& Volpi, M. (2008). The diffusion of clean technologies: a review with suggestions for future diffusion analysis. Journal of Cleaner Production, 16(1), S14-S21.

Leonidou, L. C., Katsikeas, C. S., Palihawadana, D., \& Spyropoulou, S. (2007). An analytical review of the factors stimulating smaller firms to export: Implications for policy-makers. International Marketing Review, 24(6), 735-770.

Markard, J., \& Truffer, B. (2006). Innovation processes in large technical systems: Market liberalization as a driver for radical change? Research policy, 35(5), 609-625.

Markusson, N. (2011). Unpacking the black box of cleaner technology. Journal of Cleaner Production, 19(4), 294-302.

Mejía-Dugand, S. (2013). Diffusion of Environmental Technology in a Megacity - A case study of Mexico City. Linköping University Electronic Press, Linköping. Retrieved from http://urn.kb.se/resolve?urn=urn:nbn:se:liu:diva-88401

Mejía-Dugand, S. (2015a). A city's utility company as an axis for its sustainable development: A case study of EPM of Medellín, Colombia.

Mejía-Dugand, S. (2015b). Environmental Technology and its Role in the Search for Urban Environmental Sustainability: The Dynamics of Adaptation. (1659 PhD), Linköping University Electronic Press.

Mejía-Dugand, S., Kanda, W., \& Hjelm, O. (2016). Analyzing international city networks for sustainability: a study of five major Swedish cities. Journal of Cleaner Production, 134, Part A, 61-69. doi: http://dx.doi.org/10.1016/j.jclepro.2015.09.093

OECD. (2009). Eco-Innovation in Industry:Enabling green growth. France: OECD publishing.

Osland, G. E., Taylor, C. R., \& Zou, S. (2001). Selecting international modes of entry and expansion. Marketing intelligence \& planning, 19(3), 153-161.

Rennings, K. (2014). Introduction: Global diffusion of environmental innovations. Environmental Innovation and Societal Transitions, 10(0), 1-3. doi: http://dx.doi.org/10.1016/j.eist.2013.12.005

Smith, D., Gregoire, P., \& Lu, M. (2006). Managers' perceptions of export barriers: a cross-cultural perspective of service firms. Journal of Transnational Management, 12(1), 51-68.

Stebbins, R. A. (2001). Exploratory research in the social sciences (Vol. 48): Sage.

Suarez-Ortega, S. (2003). Export barriers: insights from small and medium-sized firms. International Small Business Journal, 21(4), 403-419. doi: Doi: 10.1177/02662426030214002. 
Taye, M., Kanda, W., Krook, J., \& Lindahl, M. (2014). E-Waste in Gaborone, Botswana-Assessing The Generation, Handling Practices, and Strategies For Improvement. The Journal of Solid Waste Technology and Management, 40(4), 349-356.

Wolcott, H. F. (2008). Writing up qualitative research: Sage Publications.

WWF. (2014). The Global Cleantech Innovation Index 2014: Cleantech group LLC; WWF. 


\section{Appendix}

Table 1: Overview of selected case companies and interviewee(s) 


\begin{tabular}{|c|c|c|c|c|c|c|}
\hline $\begin{array}{l}\text { Municipally-owned } \\
\text { Company }\end{array}$ & Focus area (s) & Target markets & $\begin{array}{l}\text { Revenue } \\
(2012) \\
1000 \text { SEK }\end{array}$ & $\begin{array}{l}\text { No. of } \\
\text { employees } \\
(2012)\end{array}$ & $\begin{array}{l}\text { No. of } \\
\text { interviews }\end{array}$ & Position of interviewee \\
\hline 1. Borlänge Energi & $\begin{array}{ll}\text { - } & \text { Wastewater } \\
\text { treatment } \\
\text { - Waste-to-energy } \\
\text { solutions (biogas; } \\
\text { incineration) } \\
\text { - City planning }\end{array}$ & $\begin{array}{l}\text { Chisinau, Moldova } \\
\text { (Expertise in waste } \\
\text { water systems, } \\
\text { waste-to-energy } \\
\text { solutions and city } \\
\text { planning) } \\
\text { - Santiago, Chile and } \\
\text { Wuhan, China } \\
\text { (projects related to } \\
\text { establishing } \\
\text { environmental } \\
\text { technology centres } \\
\text { and expertise on } \\
\text { waste-to-energy } \\
\text { solutions) }\end{array}$ & 768389 & 201 & 1 & $\begin{array}{l}\text { - Head of } \\
\text { international } \\
\text { projects }\end{array}$ \\
\hline $\begin{array}{l}\text { 2. Borås Energi och } \\
\text { Miljö }\end{array}$ & $\begin{array}{l}\text { Waste-to-energy } \\
\text { solutions (biogas; } \\
\text { incineration) } \\
\text { Water and sewage } \\
\text { treatment }\end{array}$ & $\begin{array}{l}\text { Indonesia (project } \\
\text { managers for } \\
\text { organic waste to } \\
\text { biogas and landfill } \\
\text { gas extraction) }\end{array}$ & 945736 & 222 & 3 & $\begin{array}{ll}\text { - } & \text { Head strategic } \\
\text { development } \\
\text { - } & \text { Business Developer } \\
\text { - } & \text { Waste strategies } \\
& \text { communicator } \\
\end{array}$ \\
\hline 3. $C 4$ Energi $A B$ & $\begin{array}{l}\text { Waste-to-energy } \\
\text { systems } \\
\text { (incineration) }\end{array}$ & $\begin{array}{l}\text { United Kingdom and } \\
\text { Canada (as project } \\
\text { partners to private } \\
\text { consultant on pre- } \\
\text { feasibility studies for } \\
\text { district heating) }\end{array}$ & 424293 & 81 & 1 & $\begin{array}{l}\text { Chief executive } \\
\text { officer }\end{array}$ \\
\hline $\begin{array}{l}\text { 4. Eskilstuna Energi } \\
\text { och Miljö }\end{array}$ & $\begin{array}{ll}\text { - Waste-to-energy } \\
\text { solutions (biogas) }\end{array}$ & $\begin{array}{ll} & \text { Mysore, India } \\
& \text { (biogas production }\end{array}$ & 1309894 & 413 & 2 & $\begin{array}{l}\text { - } \quad \text { Acting business Area } \\
\text { manager- Recycling }\end{array}$ \\
\hline
\end{tabular}




\begin{tabular}{|c|c|c|c|c|c|c|}
\hline & & $\begin{array}{l}\text { from organic waste) } \\
\text { - } \quad \text { China (SymbioCity } \\
\text { project -sustainable } \\
\text { urban development) }\end{array}$ & & & & $\begin{array}{l}\text { - } \quad \text { Project manager } \\
\text { and process } \\
\text { engineer }\end{array}$ \\
\hline $\begin{array}{ll}\text { 5. } & \text { Gästrike } \\
\text { återvinnare }\end{array}$ & $\begin{array}{l}\text { - Solid Waste } \\
\text { recycling with } \\
\text { material and } \\
\text { energy recovery }\end{array}$ & $\begin{array}{l}\text { Poland (waste } \\
\text { management } \\
\text { education for } \\
\text { professionals) }\end{array}$ & 165459 & 91 & 1 & $\begin{array}{l}\text { - } \begin{array}{l}\text { Chief executive } \\
\text { officer }\end{array} \\
\end{array}$ \\
\hline 6. Kraftringen $A B$ & $\begin{array}{l}\text { Waste-to-energy } \\
\text { solutions (biogas; } \\
\text { incineration) }\end{array}$ & $\begin{array}{l}\text { United Kinngdom } \\
\text { and Canada (as } \\
\text { project partners to } \\
\text { private consultant } \\
\text { on pre-feasibility } \\
\text { studies for district } \\
\text { heating) } \\
\end{array}$ & 2819809 & 421 & 2 & $\begin{array}{l}\text { - } \begin{array}{l}\text { Chief executive } \\
\text { officer }\end{array} \\
\text { Business Area } \\
\text { Manager- Business } \\
\text { and Product } \\
\text { Development }\end{array}$ \\
\hline 7. Renova & $\begin{array}{l}\text { Solid waste } \\
\text { recycling with } \\
\text { material and } \\
\text { energy recovery }\end{array}$ & $\begin{array}{l}\text { - South Africa, } \\
\text { Botswana, Angola, } \\
\text { Mozambique (joint } \\
\text { seminar and } \\
\text { education on waste } \\
\text { management) }\end{array}$ & 1283203 & 993 & 1 & $\begin{array}{l}\text { Head of Strategic } \\
\text { Development }\end{array}$ \\
\hline 8. Sysav & $\begin{array}{l}\text { - } \\
\text { Solid waste } \\
\text { recycling with } \\
\text { material and } \\
\text { energy recovery }\end{array}$ & $\begin{array}{l}\text { Hong Kong (waste } \\
\text { management) } \\
\text { Toronto, Canada } \\
\text { (waste battery } \\
\text { collection; waste, } \\
\text { water and energy } \\
\text { feasibility studies) }\end{array}$ & 796467 & 285 & 1 & $\begin{array}{l}\text { - } \begin{array}{l}\text { Chief executive } \\
\text { officer }\end{array} \\
\text { of }\end{array}$ \\
\hline
\end{tabular}




\begin{tabular}{|c|c|c|c|c|c|c|}
\hline & & $\begin{array}{l}\text { collection facility) } \\
\text { Tang-Ma, China (city } \\
\text { infrastructure } \\
\text { projects) }\end{array}$ & & & & \\
\hline $\begin{array}{l}\text { 9. Tekniska Verken i } \\
\text { Linköping }\end{array}$ & $\begin{array}{l}\text { Waste-to-energy } \\
\text { solutions (biogas; } \\
\text { incineration) }\end{array}$ & $\begin{array}{l}\text { - Canada (sub- } \\
\text { contractor to private } \\
\text { consultant in district } \\
\text { heating project) } \\
\text { - } \quad \text { Poland, Romania, } \\
\text { Estonia (developing } \\
\text { waste-to-energy } \\
\text { projects by its } \\
\text { subsidiary - Usitall } \\
\text { AB, hibernating } \\
\text { since 2012) } \\
\text { Malta (optimization } \\
\text { of biogas process by } \\
\text { its subsidiary - } \\
\text { Svensk Biogas) }\end{array}$ & 5433000 & 969 & 4 & $\begin{array}{ll}\text { - } & \text { Head of business } \\
\text { development } \\
\text { - } & \text { Business } \\
\text { development } \\
\text { manager } \\
\text { - } \\
\text { - } \quad \text { Chief executing director } \\
\text { officer }\end{array}$ \\
\hline 10. Umeå Energi & $\begin{array}{l}\text { Waste-to-energy } \\
\text { solutions } \\
\text { (incineration) }\end{array}$ & $\begin{array}{ll}- & \text { Canada } \\
\text { - } & \text { China } \\
\text { - } & \text { Petrozavodsk, } \\
& \text { Russia (waste } \\
\text { management and } \\
\text { district heating) }\end{array}$ & 1525693 & 303 & 1 & - $\quad$ Business developer \\
\hline 11. Vafabmiljö & $\begin{array}{l}\text { - Solid waste } \\
\text { recycling with } \\
\text { material and } \\
\text { energy recovery } \\
\text { - } \quad \text { Biogas production }\end{array}$ & $\begin{array}{l}\text { Gaborone, } \\
\text { Botswana } \\
\text { (Independent export } \\
\text { project on municipal } \\
\text { solid waste } \\
\text { management) }\end{array}$ & 412078 & 197 & 2 & 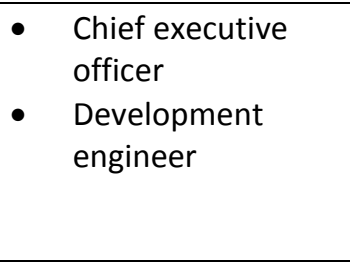 \\
\hline
\end{tabular}




\begin{tabular}{|c|c|c|c|c|c|c|}
\hline & & $\begin{array}{l}\text { - Gran Canaria } \\
\text { (anaerobic digestion } \\
\text { of organic waste) }\end{array}$ & & & & \\
\hline 12. Öresundskraft $A B$ & $\begin{array}{l}\text { Waste-to-energy } \\
\text { solutions } \\
\text { (incineration) } \\
\text { - Wind power }\end{array}$ & $\begin{array}{ll}\text { - } & \begin{array}{l}\text { Poland (biofuel } \\
\text { project) }\end{array} \\
\text { - } & \text { United Kingdom and } \\
\text { Canada (as project } \\
\text { partners to private } \\
\text { consultant on pre- } \\
\text { feasibility studies for } \\
\text { district heating) }\end{array}$ & 3043018 & 395 & 1 & $\begin{array}{l}\text { Business Area } \\
\text { Manager-heat and } \\
\text { power }\end{array}$ \\
\hline
\end{tabular}

